\title{
A DECADE OF DNA METHYLATION PROFILING IN CANCER: WHAT HAVE WE LEARNED?
}

Aditya Sharma, M.D. ${ }^{1}$ and Steven J Kuerbitz, M.D. ${ }^{1^{*}}$

${ }^{1}$ Division of Hematology/Oncology, Department of Pediatrics, Akron Children's Hospital, Akron, Ohio

* Corresponding author: 1 Perkins square, Akron Children's Hospital, Akron, Ohio, USA, 44308-1062

Phone-330-543-8580

Email: skuerbitz@chmca.org.

\begin{abstract}
Investigators have studied DNA methylation in tumor cells for nearly 50 years. Differences in gene-specific methylation between cancer cells and their normal counterparts were described more than 30 years ago. From early techniques that measured overall DNA methylation levels to enzyme-associated techniques that interrogated methylation at a single $\mathrm{CpG}$ dinucleotide to present day assays that catalogue the methylation of every cytosine in the genome, technical advancement progressively has brought increasing clarity to our understanding of the complex epigenomes of normal and neoplastic cells. Over the past 10 years we have been witness to an explosion of investigation into the epigenetic basis of cancer, and application of the powerful genome-wide DNA methylation profiling techniques to be reviewed have yielded critical insights into the organization of the cancer methylome with its broad regions of hypomethylation and foci of hypermethylation resulting in critical differences in gene expression and chromosomal stability compared to normal cells. These insights, in turn, have prompted novel, testable hypotheses, to be discussed, pertaining to fundamental aspects of cancer biology including the potential stem cell/progenitor cell origins of cancer and the plasticity of gene expression that may underlie tumor heterogeneity and tumor progression. Finally to be discussed is the growing portfolio of epigenetic tools being provided by modern methylome profiling analyses. These biomarker tools are complementing and extending the current genomic tests that are improving cancer diagnosis and that increasingly will facilitate highly individualized cancer treatment in the upcoming decade.
\end{abstract}

Keywords-epigenetics, genome-wide methylation, CpG hypermethylation, hypomethylation, microRNA 


\section{INTRODUCTION}

The term epigenetics was coined by C.H. Waddington in 1942 as a portmanteau of the words epigenesis and genetics. It was described as, "the interactions of genes with their environment, which bring the phenotype into being." (Waddington 2012). Epigenetics is the study of heritable changes other than those in the DNA sequence and encompasses two major modifications of DNA or chromatin: DNA methylation - the covalent modification of cytosine, and post-translational modification of histones including methylation, acetylation, phosphorylation and SUMOylation (Strahl and Allis 2000). DNA methylation at the carbon-5 position of cytosine (5mC), first discovered in 1948 (Hotchkiss 1948), is the most stable of all epigenetic modifications and is most prevalent at $\mathrm{CpG}$ dinucleotides. Most $\mathrm{CpG}$ dinucleotides in mammalian genomes (over $85 \%$ ) are sparsely distributed throughout the genome. A substantial percentage of these ( $40 \%$ or more) occur in repetitive sequences that can be transcribed/transposed in the genome under certain circumstances. The remaining $15 \%$ of $\mathrm{CpG}$ dinucleotides are clustered in GCrich segments that have been termed " $\mathrm{CpG}$ islands" (CGI). Approximately $40-50 \%$ of human genes have CGIs within the promoter or first exon, and expression of these genes may be affected by $\mathrm{CpG}$ methylation within the island under normal or pathologic conditions (Baylin et al. 1986). Aberrant DNA methylation - both loss of methylation and gain of methylation - represents a hallmark of cancer, and methylation-dependent epigenetic mechanisms have been implicated in the molecular pathogenesis of many forms of human neoplasms (Feinberg 2004, Baylin et al. 1998). methylcytosine and approximately 35 years since the initial descriptions of aberrant DNA methylation in cancer, we have come a long way. With the advent of genome-wide methylation profiling techniques, powerful tools now exist for the study of cancer epigenetics. In this review, we will discuss the evolution of genome-wide methylation profiling technologies and then explore applications of those techniques that are illuminating an increasingly clear and comprehensive picture of the cancer epigenome and are providing clinical tools that can better facilitate evaluation and guide therapy as that picture emerges.

\section{Evolution of genome-wide methylation profiling technologies}

Techniques to interrogate DNA methylation have progressed in scope from Southern blot analysis of single $\mathrm{CpG}$ dinucleotides to microarray hybridization assays and next generation sequencing (NGS) techniques that can profile the entire genome. Over the past couple of decades numerous DNA methylation detection techniques have been described. These methods can be broadly divided into three main categories that differ in the mechanism by which the methylation status is interrogated.

\subsection{Bisulfite modification}

Many techniques employ the principle of sodium bisulfulite-induced changes in genomic DNA. This meticulous method, developed by Frommer and colleagues (Frommer et al. 1992) relies on the deamination of cytosine residues to uracil with sodium bisulfite treatment of genomic DNA. Upon PCR-amplification of the target DNA, uracil residues are replaced with thymine. As $5 \mathrm{mC}$ residues are refractory to this modification, bisulfite treatment of genomic DNA effectively creates single nucleotide

Almost 70 years after the discovery of 5- 
polymorphisms $(\mathrm{C}$ versus $\mathrm{T})$ at sites where differential $\mathrm{CpG}$ methylation exists between samples. These single-nucleotide polymorphisms (SNPs) can then be identified using a variety of mechanisms including direct sequencing, restriction enzyme digestion, and probe hybridization.

Direct sequencing: The bisulfite converted genomic DNA (gDNA) serves as a template for PCR. Primers for bisulfite-converted gDNA can be designed to complement a sequence containing either methylated or unmethylated $\mathrm{CpGs}$ or can be localized to a region without $\mathrm{CpGs}$, so that annealing and subsequent PCR amplification are not dependent on methylation status. For bisulfite sequencing, primers are generally designed to anneal to non- $\mathrm{CpG}$ regions flanking each region of interest and thus will amplify bisulfite converted gDNA regardless of $\mathrm{CpG}$ methylation status. Cloned PCR products are then sequenced, and the methylation status of the individual $\mathrm{CpG}$ sites is ascertained by analysis of the sequence in which $\mathrm{CpGs}$ in the gDNA template that are methylated will read out as $\mathrm{CG}$ whereas $\mathrm{CpGs}$ that are unmethylated will read out as TG. The advantage of the bisulfite sequencing technique is that it provides a relatively economical and technically straightforward modality by which to analyze multiple $\mathrm{CpG}$ sites within a target sequence. The principal disadvantage is that heterogeneity of sitespecific $\mathrm{CpG}$ methylation must be approximated based on analysis of multiple sequenced clones.

Pyrosequencing: This technique is based on the "sequencing by synthesis" principle, which provides DNA sequencing in real time. The pyrosequencing method relies on detecting the activity of DNA polymerase by an enzymatic, luminometric inorganic pyrophosphate (PPi) detection assay (ELIDA) (Nyren 1987).
As the nascent DNA strand extends on the template with the addition of one of the deoxynucleotides, a PPI is released. ATPsulfurylase converts the liberated PPi to ATP in the presence of adenosine-5'phosphosulfate. This ATP acts as a substrate for the luciferase-mediated conversion of luciferin to oxyluciferin that generates visible light in amounts that are proportional to the amount of ATP. The light produced in the luciferase-catalyzed reaction can be detected quantitatively by a charged-coupled device camera. Once again, the methylation status of CpGs within the region of interest is inferred by comparison of the sequence of bisulfitemodified template DNA (CG vs $\mathrm{TG}$ ) to known genomic sequence or to that of unmodified template. Currently there are two different types of pyrosequencing techniques available, based on the type of template used, i.e. solid phase pyrosequencing and liquid phase sequencing (Ronaghi et al. 1996, Ronaghi 2001). A clear advantage of methylation analysis by pyrosequencing is that it permits the quantitative determination of methylation levels across multiple $\mathrm{CpG}$ sites within a target sequence. This quantitative readout may be of particular importance where site-specific $\mathrm{CpG}$ methylation is heterogeneous in a genomic DNA sample. A current disadvantage is the limited availability to many investigators of pyosequencing platforms and the expense of utilizing commercially-available services.

Methylation-sensitive single-strand conformation analysis (MS-SSCA): This method is based on the single-strand conformation polymorphism analysis (SSCA) method originally developed for SNP analysis. This technique is based on the principle that single-stranded DNA molecules take on specific sequence-based secondary structure in non-denaturating conditions. Molecules differing by as little as a single base pair substitution may for different conformers and migrate differently 
in a non-denaturing polyacrylamide gel (Orita et al. 1989, Sheffield et al. 1993). MS-SSCA thus detects the CG versus TG substitution in PCR products of methylated versus unmethylated, bisulfite-modified DNA templates (Bianco, Hussey, and Dobrovic 1999).

Methylation-specific PCR (MSP): MSP uses primers complementary to methylated versus unmethylated target $\mathrm{CpGs}$ within the primer sequence for end-point PCR amplification following bisulfite modification. Target methylation status is inferred from the comparison of the relative abundance of amplification products yielded by methylated-specific primers (which complement $\mathrm{CG}$ ) versus non-methylatedspecific primers (which complement UG). An advantage of MSP is that it requires only small quantities of DNA. MSP can be performed on DNA extracted from paraffinembedded samples, and the technique is sensitive to $0.1 \%$ methylated alleles of a given target locus. This method has been particularly useful in the interrogation of CGI methylation in cancer, which may have a dense concentration of methylated CpGs, as increased numbers of $\mathrm{CpG}$ pairs in the primer increase the specificity of the assay (Herman et al. 1996). The MethyLight technique is a modification of MSP that utilizes real time quantitative PCR (qPCR). It is a high-throughput quantitative methylation assay that employs fluorescence-based real-time PCR (TaqMan®) technology and requires no further manipulations after the PCR step. The modified DNA is amplified using locus-specific qPCR primer/probe pairs. Because the sensitivity of the DNA methylation analysis is further improved by approximately two orders of magnitude, this real-time PCR technique represents an extremely flexible platform for highsensitivity quantitative DNA methylation analysis of small DNA samples. The major advantage of this technique is the sensitive real-time detection of PCR products, thus eliminating the need for gel electrophoresis or other downstream analysis of PCR products and enabling analysis of minute quantities of DNA (Eads et al. 2000).

Microarray based techniques: Micro-array based techniques that identify the $\mathrm{C} / \mathrm{T}$ polymorphism yielded by bisulfite treatment of differentially methylated DNA samples represent the next step in the evolution of genomic methylation analysis. By providing robust techniques for interrogating thousands of $\mathrm{CpG}$ targets genome-wide, these assays have revolutionized the field of cancer epigenetics. Array-based DNA methylation profiling was first described in early 2000. For these techniques, targets of interest (usually 300-400 bp in size) are PCR-amplified from bisulfite-treated template DNA. The amplified PCR products are hybridized to glass slides to which have been immobilized a pair of oligonucleotides for each $\mathrm{CpG}$ target that complement converted (CG) versus unconverted (TG) cytosines at the $\mathrm{CpG}$ site of interest, thereby providing a readout of the original methylation state at that site. Earlier microarrays analyzing bisulfite-modified DNA utilized locus-specific primers for amplification of targets of interest and subsequent hybridization to a dedicated oligonucleotide array. Because the genomic representation yielded by these techniques was limited, they did not represent genomewide analysis techniques in the truest sense (Gitan et al. 2002). More recently, techniques such as bisulfite methylation profiling (BiMP) have employed random oligonucleotide priming of bisulfiteconverted DNA to facilitate whole genome PCR amplification that is sufficiently representative and unbiased to be regarded as true genome-wide methylation profiling (Reinders et al. 2008).

Currently many commercial highdensity oligonucleotide arrays are 
available, and these have been widely adopted because they offer great precision and potentially can yield quantitative readouts of $\mathrm{CpG}$ methylation in genomic DNA samples. Currently-available methylation microarray formats include the photolithographic masked arrays of Affymetrix, the photolithographic adaptive optics arrays of NimbleGen, and the inkjet arrays of Agilent. The adaptation of bead arrays for interrogation of the CT polymorphisms resulting from bisulfite modification of differentially-methylated DNA genomic samples made technically feasible the exponential expansion of $\mathrm{CpG}$ site density to that now available in genomewide methylation profiling assays (Bibikova et al. 2006). The current bead array assay from Illumina (Infinium $\square$ HumanMethylation450 BeadChip) interrogates more than $450,000 \mathrm{CpG}$ sites (both CGI and non-island) and provides nearly complete representation of RefSeq genes. These high throughput techniques now provide the opportunity for a much more comprehensive genome-wide methylation analysis of the cancer methylome (Bibikova et al. 2009).

MethylC-seq: Clearly, a fully comprehensive analysis of DNA methylation requires interrogation of every base in the genome. Methylation profiling at single nucleotide resolution is achievable utilizing the MethylC-seq technique. Genomic DNA is fragmented and ligated to sequencing adaptors. DNA is then bisulfite modified, PCR-amplified, and sequenced by means of NGS technologies (Lister et al. 2008).

\subsection{Methylation-sensitive restriction enzymes}

Many restriction endonucleases containing $\mathrm{CpG}$ dinucleotides within the cognate sequence are sensitive to methylation, in that they will digest DNA only if the $\mathrm{CpG}$ is unmethylated. Isoschizomer pairs also exist that differ in digestion of methylated versus unmethylated CpGs within the same cognate sequence. For example, HpaII digests DNA at the sequence CCGG only if the $\mathrm{CpG}$ is unmethylated whereas MspI cuts the same sequence regardless of the $\mathrm{CpG}$ methylation status. This differential digestion has been exploited in a number of techniques to identify loci of differential methylation between genomic DNA samples.

\section{Methylation Restriction Landmark Genome Scanning (RLGS): This two- dimensional electrophoresis approach utilizes methylation-sensitive restriction} endonuclease digestion to identify sites of differential $\mathrm{CpG}$ methylation between 2 genomic DNA samples. RLGS was the first genome-wide profiling method that allowed positional information to be derived with respect to the genomic location where changes in methylation have occurred. In this technique, DNA is digested with a methylation-sensitive restriction endonuclease and then is radiolabeled at the digestion ends. Following digestion with a second, non-methylation sensitive enzyme, the DNA is fractionated by electrophoresis in a tubular polyacrylamide gel. The DNA is then digested in-gel with a third enzyme, and fragments are fractionated by polyacrylamide gel electrophoresis (PAGE) in the second (perpendicular) dimension. Differential migration of fragments between genomic DNA samples (different "spots" identified on comparison of autoradiographic images), then, represent sites of differential DNA methylation. By choosing a methylation-sensitive restriction endonuclease with a GC and CpG-rich cognate sequence (e.g., NotI GCGGCCGC), the methylation analysis can be biased toward CGIs. RLGS can provide a quantitative epigenetic assessment of thousands of CGIs in a single gel without prior knowledge of gene sequence (Costello et al. 2000).

HELP (HpaII tiny fragment Enrichment by Ligation-mediated PCR): The HELP 
assay is a quantitative restriction enzymebased assay that interrogates methylation within $\mathrm{CpG}$ islands andother CpG-rich genomic regions at high resolution $(\sim 200$ bp). Paired genomic DNA samples are digested with the isochizomers HpaII (methylation sensitive) or MspI (methylation insensitive). Ligationmediated PCR amplification yields enriched representation of small (i.e., unmethylated) fragments in the HpaII fraction. Comparative hybridization onto a customized array of the HpaII representation (unmethylated fragments) versus the MspI representation (all fragments) then permits quantitative determination of methylation at the loci interrogated by the array (Khulan et al. 2006).

Amplification of intermethylated sites (AIMS) is a ligation-mediated PCR-based technique in which no prior sequence information is required for amplification. The method employs the differential cleavage of isochizomers with distinct methylation sensitivity. The non-methylated sites are cut in a first digestion using the methylation sensitive SmaI restriction endonuclease (CCCGGG), which leaves blunt ends. A second digestion is performed using the isoschizomer PspAI, which is methylation insensitive and leaves a CCGG overhang.

Specific adaptors are ligated to the PspAIdigested (methylated) ends of the digested genomic DNA. Digestion fragments are then PCR amplified using adaptor-specific primers. PAGE then yields fingerprints consisting of multiple anonymous bands, each representing a DNA sequence flanked by two methylated CCCGGG sites. Differential bands between genomic DNA samples can be isolated and characterized (Frigola et al. 2002). Other examples include Methylation-sensitive Arbitrary primed PCR (Gonzalgo et al. 1997), and Methylated CpG-island Amplification (MCA) (Toyota, Ho, et al. 1999).

\subsection{Immunoprecipitation-based techniques.}

Chromatin immunoprecipitation (ChIP) is used to identify the location of DNAbinding proteins and epigenetic marks in the genome. Genomic sequences containing the mark (e.g., specific histone modification) of interest are enriched by immunoprecipitation of soluble DNA chromatin extracts using an antibody that recognizes the mark. Immunoprecipitation is followed by microarray hybridization (ChIP-chip) or next-generation sequencing (ChIP-seq) (Guenther et al. 2007, Robertson et al. 2007). Enrichment for regions of methylated DNA achieved using antibodies specific for $5 \mathrm{mC}$ (in the context of denatured DNA) or using DNA binding proteins with affinity for $5 \mathrm{mC}$ in native genomic DNA similarly permit DNA methylation analysis. These techniques provide powerful tools for extensive DNA profiling in complex genomes. ChIP is has been utilized extensively to studying the histone modifications that characterize various chromatin conformations. The first whole genome DNA methylation map was reported for Arabidopsis thaliana using the methylcytosine immunoprecipitation technique (mCIP) (Keshet et al. 2006) to yield a DNA methylation map of the entire genome at 35 base pair resolution. For this study, methylated and unmethylated DNA fractions were isolated using an antimethylcytosine monoclonal antibody. DNA fragments were identified with wholegenome tiling microarrays (mCIP-chip method) (Zhang et al. 2006, Zilberman et al. 2007).

2. DNA methylation profiling, gene dysregulation, and cancer biology

The role of DNA methylation in tumorigenesis is now well substantiated by the evidence amassed from numerous studies examining the role of epigeneticallydysregulated genes in 
various cancers. Aberrant hypermethylation of CGIs comprising the regulatory regions of genes may result in transcriptional repression. Accordingly, many genes that are epigenetically-dysregulated in cancers are known tumor suppressor genes or have otherwise been linked to tumor progression. These genes have functional roles in cell homeostasis and participate in diverse processes such as cell cycle, DNA repair, apoptosis, angiogenesis, cellular motility, cell adhesion, and others. Many of these genes were identified as targets of epigenetic dysregulation in cancer using earlier locusspecific techniques. Through genome-wide methylation profiling experiments, though, the roles of some genes in cancers have been expanded and refined and new gene targets have been identified.

\subsection{Tumor suppressor genes}

Upstream methylation of the retinoblastoma gene $(R B)$ in sporadic retinoblastoma was the first example of putative silencing of a tumor suppressor gene via aberrant DNA methylation to be described in human cancer (Sakai et al. 1991, Greger et al. 1989). Subsequent studies have identified a number of other genes, including $B R C A 1$, $p 16 / C D K N 2 A, A P C$ - all tumor suppressor genes subject to transcriptional repression associated with aberrant CGI methylation in human cancers (Jones 2002). CDKN2A (p16) is an inhibitor of cyclin-dependent kinase 4 (CDK4) and CDK6 and functions as a tumor suppressor. $C D K N 2 A$ expression is upregulated with cellular senescence and increases markedly with aging in a wide variety of human tissues (Collado, Blasco, and Serrano 2007). In a survey of different primary human neoplasms, de novo methylation of the $C D K N 2 A 5^{\prime} \mathrm{CpG}$ island was identified in approximately $20 \%$ of cases whereas the region was invariably unmethylated in normal tissues (Merlo et al. 1995).

\subsection{The CpG island methylator phenotype in cancer}

Among the cancers in which CDKN2A promoter hypermethylation and associated transcriptional silencing were first documented is colon cancer (Herman et al. 1995, Gibson et al. 2005). Importantly, hypermethylation at this site in colorectal carcinoma (CRC) has been associated with a $\mathrm{CpG}$ island methylator phenotype (CIMP). The CIMP is characterized both by more widespread CGI methylation and by methylation which affects a unique subset of CGI loci (Toyota, Ahuja, et al. 1999). In analyses of large numbers of CRCs, including population based analyses, CIMP was highly associated with mutations of $B R A F$ ( $\left.{ }^{V 600 E} B R A F\right)$ and KRAS2 (Weisenberger et al. 2006, Samowitz et al. 2005). Because early designations of CIMP in CRC typically were defined based on interrogation of a small number of CGIs, the validity of the phenotype has been challenged. Application of genome-wide methylation profiling approaches has provided some clarification to this question. In a recent analysis employing methyl-CpG binding domain protein (MDP) capture of methylated segments coupled with NGS (MiGS or MDP-seq), investigators identified significantly increased and unique sites of CGI methylation in CIMP-positive tumors compared to CIMP-negative tumors (Xu et al. 2012). Similarly, a methylome analysis of CRC samples employing the Infinium HumanMethylation27 assay (Illumina), which interrogates more than $27,000 \mathrm{CpG}$ sites in the promoter regions of more than 14,000 genes and microRNAs identified variable extents and patterns of CGI methylation corresponding to CIMP status (Hinoue et al. 2012).

The microsatellite instability (MSI) phenotype is observed in about $15 \%$ of CRC cases and results from the genetic inactivation of the DNA mismatch repair genes $M L H 2, M L H 1, M S H 6$ or PMS2 in hereditary CRCs (Boland and Goel 2010) or with CGI methylation-associated inactivation of $M S H 1$ in sporadic CRCs 
(Herman et al. 1998, Cunningham et al. 1998). Methylation-associated inactivation of $M L H 1$ and associated MSI is highly coincident with the CIMP-high phenotype (Samowitz et al. 2005, Hinoue et al. 2012). In recent studies, integrated analysis of genetic and epigenetic phenotypes (e.g., MSI and CIMP) has identified CRC subtypes with distinctive molecular characteristics and clinical features (Shen et al. 2007, Simons et al. 2013). It is likely that broadened application of methylome profiling approaches will serve to further define such classification schemata and guide therapeutic management.

Based on methylome and target gene analyses, a CpG island methylator phenotype has now been postulated for numerous other cancer types (Hughes et al. 2013). The CIMP-high phenotype has been associated with an adverse prognosis in clear cell carcinoma of the kidney (Arai et al. 2012), melanoma (Tanemura et al. 2009), and myelodysplastic syndrome (Zhao et al. 2014). By contrast, a methylation analysis of a large set of breast cancer cohort recently demonstrated a lower risk for metastatic failure in the CIMPpositive group (Fang et al. 2011). Integrating transcriptome analysis with methylation profiling data for the CIMPpositive group, these investigators then identified transcriptional downregulation of genes mediating cell motility and epithelialmesenchymal transition, among others. A remaining challenge is to achieve some uniformity of methylation-based definitions of CIMP within and across tumor types, which will facilitate the clinical utility of this marker.

Interestingly, the available evidence suggests a genetic basis for the epigenetic $\mathrm{CpG}$ island methylator phenotype. The association of CIMP-high with ${ }^{{ }^{6} 00 E} B R A F$ in CRC has been noted. In a study of gliomas, investigators correlated CIMPpositive phenotype with improved prognosis and with somatic mutations of the IDH1 gene (Noushmehr et al. 2010). A

critical mechanistic link was then provided by Turcan and colleagues who found that introduction of a mutant IDHI gene into primary human astrocytes resulted in reprogramming of the methylome and established the CIMP in these cells (Turcan et al. 2012). These investigators further demonstrated that mutant IDHI acted to inhibit histone demethylation resulting in the accumulation of repressive histone methylation ( $\mathrm{Lu}$ et al. 2012). Interestingly, in this experiment, which utilized immortalized, but not malignant preadipocytic mouse embryo fibroblasts, the accumulation of histone methylation was not accompanied by changes in DNA methylation.

\subsection{Methylation gene dysregulation in other cancers}

Early candidate gene methylation analyses documented methylation-associated silencing of estrogen receptor (Piva et al. 1990, Falette et al. 1990) and BRCA1 (Dobrovic and Simpfendorfer 1997, Esteller, Silva, et al. 2000) and substantiated a role for aberrant methylation in the oncogenesis of breast cancer. Genome-wide methylation profiling studies have identified additional gene targets of CGI methylationassociated silencing in breast cancer. Utilizing the Human Methylation27 beadchip assay, Hill and colleagues identified novel gene targets including RECK and $A C A D L$, methylation of which was associated with decreased expression and with poor prognosis (Hill et al. 2011). Results such as these are consistent with the now well-established paradigm of transcriptional repression of putative tumor suppressor genes via aberrant hypermethylation. Other recent methylome analyses have suggested a more nuanced role for DNA methylation in breast cancer. Caveolin-1 (CAV1) is a plasma membrane- 
associated scaffold protein that plays a role in signal transduction among other processes (Liu, Rudick, and Anderson 2002). Interestingly, both tumor suppressor and oncogenic roles have been proposed for CAV1 in breast cancer (Chiu et al. 2011, Savage et al. 2007). Rao and colleagues used an MDP-seq approach to analyze breast cancer cell lines and primary tumors and found that CAVI expression was upregulated in associated with hypomethylation of the CAVI 5, CGI "shore", a region upstream of the CGI with a decreased $\mathrm{CpG}$ frequency (Rao et al. 2013). These findings indicate that neoplasia-associated methylation changes in gene regions other than CGIs can affect gene expression.

Whole-genome methylation profiling techniques have likewise been utilized in analyses of childhood malignancies. These studies have identified novel gene targets of epigenetic dysregulation in childhood acute lymphoblastic leukemia (ALL) (Chatterton et al. 2014, Davidsson et al. 2009), neuroblastoma (Djos et al. 2012), and Wilms' tumor (Charlton et al. 2015). Prognostic differences have been shown between subgroups defined by methylation signatures in neuroblastoma (Decock et al. 2012), B-lineage ALL (Sandoval et al. 2013), and in T-cell ALL, where investigators identified a CIMP associated with a poorer prognosis in CIMP-negative patients (Borssen et al. 2013). If further studies substantiate the contribution of novel prognostic information from methylome analysis, then integration of epigenotypic markers into the molecular, cytogenetic, histologic, and clinical classification schemata currently employed will follow, particularly if therapies directed at the modification of epigenetic marks are shown to be effective.

In view of the explosion of investigation in the field of cancer epigenetics in the last 20 years, it is no longer feasible to comprehensively review all gene targets of epigenetic dysregulation in all cancers. It must suffice to note that examples of epigenetic gene dysregulation have been documented relevant to cell homeostatic processes pertinent to cancer including apoptosis (Kissil et al. 1997, Katzenellenbogen, Baylin, and Herman 1999), cell adhesion (Graff et al. 1995, Graziano et al. 2004) and angiogenesis (Okochi-Takada et al. 2014).

\subsection{MicroRNA}

MicroRNAs are small non-coding RNAs that regulate the expression of complementary messenger RNAs and function as key regulators of myriad cellular processes, including proliferation, differentiation and apoptosis. It is estimated that at least $30 \%$ of all human genes are regulated by miRNAs (Lewis, Burge, and Bartel 2005). The latest release of the Sanger miRNA Registry ( http://microrna.sanger.ac.uk) annotates more than 1800 human miRNAs (release 21.0). There is increasing evidence to indicate that a sizable number of microRNA genes are subjected to epigenetic dysregulation in cancer. It has been known for some years that both overexpression and depletion of miRNA loci can play pathogenic roles in tumor progression (Hammond 2006). One of the first instances of an miRNA characterized as oncogenic was the mir-1792 cluster, which is amplified in human Bcell lymphomas and can enhance tumor growth in mouse models (He et al. 2005). Other examples of miRNAs that might have oncogenic or tumor suppressor roles include $\mathrm{BIC} / \mathrm{miR}-155$, which is overexpressed in $\mathrm{B}$ cell lymphomas (Eis et al. 2005), and Let-7 miRNAs, which downregulate the expression of $R A S$ oncogenes in $\boldsymbol{C}$. elegans and in human cells (Johnson et al. 2005), and depletion of which appears to enhance tumorigenicity in lung and colon cancers (Johnson et al. 2005, Akao, Nakagawa, and 
Naoe 2006). As has been seen with proteincoding genes, epigenetic reprogramming in cancer cells can result in dysregulated expression of miRNAs and so contribute to tumorigenesis (Kunej et al. 2011). Thus, miRNA genes may be silenced in human tumors by aberrant hypermethylation of CGIs that encompass or lie adjacent to miRNA genes promoters and/or by histone modifications (Lehmann et al. 2008, Taube et al. 2013). Conversely, hypomethylation may be associated with upregulation of oncogenic miRNAs (Loriot et al. 2014). A straightforward technique whereby epigenetically-downregulated miRNA may be identified in cancer cells couples pharmacologic unmasking of miRNA expression by treatment of tumor cells with a demethylating agent and/or an inhibitor of histone deacetylation (HDAC) and miRNA expression profiling. Tumor suppressor miRNAs and miRNA biomarkers have been identified by this approach (Choudhry and Catto 2011, Heller et al. 2012).

Recent studies have addressed the potential role of miRNA to induce epigenetic reprograming in cancer cells. Ogawa et al. showed that miR-302s and miR-369s could induce cellular reprogramming and modulate malignant phenotypes of human colorectal cancer in vivo, suggesting that the appropriate delivery of functional small-sized ribonucleotides may open a new avenue for therapy against human malignant tumors. They demonstrated that global epigenetic alterations such as DNA demethylation occur in miR-302stransfected colorectal cancer cells, which might result in reactivation of tumor suppressor genes that have been epigenetically downregulated in cancer cells (Ogawa et al. 2015).

\section{Epigenetic topography, chromatin states, stem cells, and cancer phenotypes}

A central question in the early years of cancer epigenetics research pertained to the organization of the cancer epigenome. The emerging picture suggested foci of acquired hypermethylation at CGIs dispersed in a genome that, overall, was undermethylated compared to normal cells (Goelz et al. 1985, Spandidos 1986, de Bustros et al. 1988). But were these clustered foci, or were they scattered throughout the genome, and were regions of hyper- and hypomethylation random or recurrent in cancer cells? With the advent of robust methodologies for DNA methylation profiling, a consistent view of the methylation landscape in the cancer cell has come into better focus.

\subsection{Methylation domains, long range epigenetic silencing, and nuclear architecture}

Recent studies have indicated that extended zones of epigenetic repression encompass clusters of hypermethylated CGIs in a phenomenon termed "long range epigenetic silencing", and that these regions are reproducible within, and in some cases, between tumor types (Novak et al. 2008, Kang et al. 2015, Jadhav et al. 2015). Berman and colleagues employed next generation sequencing of bisulfite-modified DNA (see MethylC-seq above) and methylation bead arrays to analyze colorectal carcinomas and found that foci of hypermethylation predominantly were embedded in large domains $(>100 \mathrm{~kb})$ of hypomethylated DNA that corresponded to nuclear lamina-associated domains (Berman et al. 2012). Integrating CHIP-seq (see above) data for histone-DNA associations, these investigators further noted that methylated $\mathrm{CpG}$ island promoters characteristically exhibited chromatin marks of the repressed but poised for transcription, or "bivalent", chromatin configuration typical of lineage-commitment and differentiation-associated genes in embryonic stem cells (ESCs) and induced pluripotent stem cells (iPSCs) (Lesch and Page 2014, Lister et al. 2011). 
Remarkably, integrated genome-wide methylation chromatin analyses undertaken by $\mathrm{Ohm}$ and colleagues have shown that the subset of CGI-associated genes, including tumor suppressor genes, silenced by aberrant hypermethylation in cancers indeed coincides extensively with a group of genes exhibiting the bivalent "poised" chromatin conformation in ESCs and iPSCs. In ESC/iPSCs, the CGI promoters of these transcriptionally poised genes carry both the repressive $\mathrm{H} 3 \mathrm{~K} 27 \mathrm{me}$ (methylation of the lysine at position 27 of the core histone $\mathrm{H} 3$ protein tail) and the active H3K4me Polycomb group (PcG) histone protein modifications and are not methylated, whereas in cancer cells they acquire 2 additional repressive chromatin marks, $\mathrm{H} 3 \mathrm{~K} 9 \mathrm{me} 2$ and $\mathrm{H} 3 \mathrm{~K} 9 \mathrm{me} 3$, as well as CGI methylation resulting in stable transcriptional silencing (Ohm et al. 2007). This observation has profound implications for our understanding of the origins of cancer, suggesting that DNA hypermethylation at CGI promoters is not a random event, but occurs as a result of an "instructive" process. A critical mechanistic link between the polycomb marks and CGI methylation in cancer cells is provided by the finding that the $\mathrm{PcG}$ complex component EZH2 interacts with DNA methyltransferases and may thereby regulate DNA methylation (Vire et al. 2006). Additionally, as a bivalent chromatin state at lineage-commitment genes serves to preserve pluripotency and self-renewal - that is to say "stemness" - in ESCs, these results suggest that epigenetic repression of many of the same genes in cancer cells may reflect a stem cell/progenitor cell origin for these cancers. Indeed, Baylin's group profiled genes exhibiting polycomb markings in ESCs, and CGI hypermethylation of a subset of these genes defined a stem cell signature across cancer types (Easwaran et al. 2012). Interestingly, while it has been suggested that metastatic potential is related to the stem cell phenotype in cancer, a recent methylation profiling analysis revealed that most hypermethylation differences between primary breast cancers and paired metastases affected non-CGI DNA and involved genes that were not polycomb related (Reyngold et al. 2014). Nevertheless, Tiwari and colleagues have demonstrated that upregulation of the transcription factor SOX4 by TGF- $\beta$ treatment of mammary epithelial cells induced epithelial-mesenchymal transition (EMT), a process central to metastasis in breast cancer, by inducing EZH2 expression (Tiwari et al. 2013). Presumably, additional study will clarify the role of epigenetic reprogramming in stem cell-associated phenotypes such as EMT, metastasis, and drug resistance.

\subsection{Global hypomethylation in cancer}

Although DNA hypomethylation was the initial epigenetic abnormality recognized in human tumors (Gama-Sosa et al. 1983, Feinberg and Vogelstein 1983), relatively more effort has thus far been focused on hypermethylation-related epigenetic dysregulation in cancer biology. Progress in genome-wide methylation profiling techniques, however, has facilitated detailed mapping of domains of undermethylated DNA in cancer cells and investigation into the role of hypomethylation in carcinogenesis has intensified. Early studies of DNA methylation in cancer cells correlated baseline or induced gene-specific hypomethylation with gene expression (Christman et al. 1977, Liteplo, Frost, and Kerbel 1984, Kelley et al. 1988). Numerous other studies have focused on repetitive DNA elements as targets of hypomethylation in the cancer genome (Dante 1988, Costa et al. 2006, Ehrlich et al. 2006). Hypomethylation of repetitive elements has been associated with chromosomal instability in tumors, 
perhaps by facilitating aberrant recombination events (Richards et al. 2009, Daskalos et al. 2009, Nishida et al. 2013).

As noted above, methylome profiling experiments now indicate that about half of the cancer genome consists of large $(>100$ $\mathrm{kb})$ bocks of hypomethylated DNA, and these include those regions enriched for repetitive elements. Interestingly, gene expression analyses have shown transcriptional activation of some genes associated with such hypomethylation (Hernandez- Vargas et al. 2011) and repression of others (Hon et al. 2012). A key to reconciling this apparent paradox is the observation by Feinberg and colleagues that variability of DNA methylation within these hypomethylated domains and variable expression of genes localized therein is a hallmark of the cancer methylome (Hansen et al. 2011). Synthesizing these observations, Feinberg and Timp have proposed an elegant, stochastic model whereby disruption of the cancer epigenome, including hypomethylation of large domains, degradation of methylation boundaries at $\mathrm{CpG}$ islands with associated hypermethylation, and dysregulation of epigenetic modifiers, among other processes, all contribute to marked variability of gene expression resulting in tumor heterogeneity that drives selective tumor progression (Timp and Feinberg 2013).

\section{Methylation biomarkers in diagnosis and prognosis}

Biomarkers can be used prior to diagnosis to assess risk of a disease, they can be applied to diagnosis, or they may be employed postdiagnosis to stratify patients according to prognosis or to predict or confirm treatment response. There are several advantages to the use of DNA methylation signals as biomarkers. Methylation marks such as hypermethylation of specific CGIs may be absent in non-neoplastic tissue and so may be quite tumor-specific. Secondly, the test substrate, tissue DNA, is readily available from a variety of sources and is a stable

molecule. DNA methylation is the most robust epigenetic mark and will survive typical sample processing procedures and storage conditions. DNA methylation can be determined in histological specimens such as formalin-fixed, paraffin-embedded (FFPE) samples (Thirlwell et al. 2012) and microscopic preparations (Wong et al. 2012). Finally, it may reasonably be anticipated that sensitive techniques for methylation detection and quantification amenable to biomarker identification will become progressively easier and more economical to perform in the clinical setting. Indeed, reliable tests to detect the altered methylation patterns of cancer cell DNA in samples of plasma, stool, sputum and urine sediments - samples that can easily be obtained via relatively noninvasive means - have been well received and are highlighted in publications pertaining to various cancer types.

\subsection{DNA methylation biomarkers for cancer detection and tumor progression}

A number of methylation markers in CRC have been translated into clinical screening tests. Methylation of the vimentin gene (VIM) has been exploited as a biomarker for early detection of colon cancers. VIM is methylated in colorectal cancers but not in normal colorectal mucosa or other healthy tissues, and such methylation is readily detectable in stool samples. For these reasons it became the first commercially available DNA methylation diagnostic test, and studies have indicated a sensitivity of $83 \%$ and specificity of $82 \%$ (Chen et al. 2005, Itzkowitz et al. 2008). Likewise, septin 9 (SEPT9), is a hypermethylation biomarker for CRC. In a blinded study the SEPT9 plasma assay showed a sensitivity of $67 \%$ and specificity of $89 \%$ for detection of colorectal cancer (deVos et al. 2009, 
Tanzer et al. 2010). Based on preclinical data from such studies, the PRESEPT trial, a prospective, population-based study to determine the clinical performance of SEPT9 for colorectal cancer screening of guideline-eligible individuals, opened in 2009 and closed recently with publication of results anticipated in the near future. ( ClinicalTrials.gov Identifier: NCT00855348) (Payne 2010).

As is the case for many malignancies, $C D K N 2 A / p 16$ is inactivated by promoter methylation in lung cancer. A meta-analysis of 19 cross-sectional studies looking at the correlation between cigarette smoking and CDKN2A hypermethylation in non-small cell lung carcinoma found a positive correlation. The positive association between cigarette smoking and CDKN2A hypermethylation was similar in adenocarcinoma and squamous-cell carcinoma (Zhang et al. 2011). Another methylation biomarker, $S H O X 2$, has been extensively investigated and is currently available as commercial screening test. It has proven to be clinically useful as a tumor marker for identifying subjects with lung carcinoma, especially if histological and cytological findings after bronchoscopy are ambiguous (Schmidt et al. 2010). The reported sensitivity and specificity for SHOX2 as a plasma-based methylation screen is $60 \%$ and $90 \%$, respectively (Kneip et al. 2011). Herman and colleagues demonstrated that hypermethylation of $C D K N 2 A$ and the O6-methylguanine DNA methyltransferase gene (MGMT) was detectable in sputum DNA as early as 35 months before lung cancer was clinically evident. Excellent concordance was noted between the CDKN2A and/or MGMT methylation components of the sputum test up to 3 years before and at the time of squamous cell lung carcinoma SCC diagnosis (Palmisano et al. 2000).

In demonstration of the power of profiling methodologies combined with comparative tumor analyses for biomarker identification, Andresen and colleagues employed pharmacologic unmasking experiments to identify targets of aberrant DNA
Hypermethylation in cholangiocarcinoma cell lines, yielding a panel of potential biomarkers including CDO1, DCLK1, ZSCAN18 and SFRP1. Scoring a positive test for methylation of any one of the 4 targets, the panel yielded a sensitivity of $87 \%$ and a specificity of $100 \%$ for identification of cholangiocarcinoma tumor samples (Andresen et al. 2012). Examining the methylation profiles for these markers across various gastrointestinal malignancies, these investigators subsequently noted combined sensitivity of $95 \%$ and a specificity of $98 \%$ in CRC tumor samples. These findings exemplify the importance of cross-tumor analyses, especially facilitated through the activities of, The Cancer Genome Atlas (TCGA) Pan-cancer project ( http://cancergenome.nih.gov/), which catalogues molecular abnormalities among various cancers (Vedeld et al. 2015).

\subsection{Epigenetic markers as predictors and monitors of treatment response}

At present $M G M T$ provides the best example of a pharmacoepigenomic biomarker in clinical use as a predictor of treatment response. MGMT encodes for the DNA repair protein O6 - methylguanine DNA methyltransferase which removes alkyl groups from the O6 -position of guanine residues and so repairs the DNA lesions of alkylating agent chemotherapy. By silencing $M G M T$ gene expression, methylation of the $M G M T$ promoter may predict responsiveness of the tumor to alkylating agents. Specifically, in a subgroup of glioma patients MGMT CGI hypermethylation was associated with reduced $M G M T$ activity and with greater tumor sensitivity to alkylating agent exposure (Esteller et al. 1999, Esteller, Garcia-Foncillas, et al. 2000). Testing for $M G M T$ promoter DNA methylation in CNS tumor tissue is now commercially available (Predict ${ }^{\mathrm{TM}}$ Brain Cancer, MDxHealth).

Methlyation markers theoretically could can 
provide pharmacodynamic endpoints for hypomethylating agents therapy. Yan et al reported a phase II trial of acute myeloid leukemia (AML) patients treated with decitabine, a DNA hypomethylating azanucleoside. This study assessed the genome-wide activity of decitabine by profiling the pretreatment and posttreatment methylomes of marrow samples from the AML patients. It was noted that decitabine significantly reduced global methylation in marrow samples compared with the pretreatment baseline. Five classifier genes - SMG6, SRR, E2F1, $B L R 1 / C X C R 5$, and $L C K$ - showed posttreatment hypomethylation changes. Hypomethylation occurred predominantly in CGI and CGI-associated regions $(\mathrm{CpG}$ island shores, $\mathrm{CpG}$ inlands, and miRNAassociated CGIs). The complete response rate in this previously untreated but older patient population was $43 \%$ with acceptable toxicity. Additional studies will be needed to determine whether the molecular (demethylation) response predicts clinical response to decitabine therapy (Yan et al. 2012). In a similar study, investigators examined the association of DNA methylation response to clinical outcome in patients with myelodysplastic syndrome treated with decitabine. Aberrant CGI promoter methylation of 10 genes $(\mathrm{CDH} 1$, CDH13, ER, NORI, NPM2, OLIG2, $C D K N 2 B / p 15, P G R A, P G R B, P D Z)$ was analyzed as a molecular monitor of therapy in this study. Although a significant association between methylation at baseline and clinical response to decitabine treatment was not evident, reduced methylation over time was correlated with better

clinical response. This study highlights the use of a panel of DNA methylation biomarkers to determine molecular and clinical response to epigenetic modulation therapy. Whether or not molecular response may be used to guide therapy remains to be determined (Shen et al. 2010). In all of these examples, it is clear that the application of integrated methylome and expression profiling techniques most rapidly provides candidate markers that may be validated to interrogate the clinical events in question.

\section{CONCLUDING REMARKS}

It is hoped that the reader of this review will appreciate the extent to which the application to cancer investigation of genome-wide DNA methylation profiling techniques, particularly when integrated with genomic and/or expression analyses, has advanced our understanding of the origins, biology, and clinical evaluation of cancer. It seems clear that as we seek to achieve a comprehensive molecular description of cancers to guide clinical management at presentation and at major decision points, to adopt a strategy that exclusively addresses one component of the cancer cellular "biome" is to limit the potential success of this approach. Rather, it would appear likely that an analysis that integrates genomic, epigenomic, transcriptomic, (and possibly proteomic) data will optimally provide the range of markers that could adequately encompass the heterogeneity within current tumor subsets. From an epigenetic standpoint, there is a need for a deeper and wider understanding of the cancer epigenome to facilitate a molecular understanding of complex phenotypes such as metastasis and drug resistance or, indeed, inform a shift of therapeutic focus to the stem cell fraction of tumors. To achieve such a granular molecular description in an economicallyfeasible way will be challenging. The view back over the past decade of DNA methylation research in cancer, however, provides cause for optimism.

\section{CONFLICT OF INTEREST}

None of the authors has any conflict of interest to disclose. 


\section{REFERENCES}

Akao, Y., Y. Nakagawa, and T. Naoe. 2006.

"let-7 microRNA functions as a potential growth suppressor in human colon cancer cells." Biol Pharm Bull 29 (5):903-6.

Andresen, K., K. M. Boberg, H. M. Vedeld, H. Honne, M. Hektoen, C. A. Wadsworth, O. P. Clausen, T. H. Karlsen, A. Foss, O. Mathisen, E. Schrumpf, R. A. Lothe, and G. E. Lind. 2012. "Novel target genes and a valid biomarker panel identified for cholangiocarcinoma." Epigenetics 7 (11):1249-57. doi: 10.4161/epi.22191.

Arai, E., S. Chiku, T. Mori, M. Gotoh, T. Nakagawa, H. Fujimoto, and Y. Kanai. 2012. "Single-CpG-resolution methylome analysis identifies clinicopathologically aggressive $\mathrm{CpG}$ island methylator phenotype clear cell renal cell carcinomas." Carcinogenesis 33 (8):1487-93. doi: 10.1093/carcin/bgs177.

Baylin, S. B., J. G. Herman, J. R. Graff, P. M. Vertino, and J. P. Issa. 1998. "Alterations in DNA methylation: a fundamental aspect of neoplasia." Adv Cancer Res 72:141-96.

Baylin, S. B., J. W. Hoppener, A. de Bustros, P. H. Steenbergh, C. J. Lips, and B. D. Nelkin. 1986. "DNA methylation patterns of the calcitonin gene in human lung cancers and lymphomas." Cancer Res 46 (6):2917-22.

Berman, B. P., D. J. Weisenberger, J. F. Aman, T. Hinoue, Z. Ramjan, Y. Liu, H. Noushmehr, C. P. Lange, C. M. van Dijk, R. A. Tollenaar, D. Van Den Berg, and P. W. Laird. 2012. "Regions of focal DNA hypermethylation and long-range hypomethylation in colorectal cancer coincide with nuclear laminaassociated domains." Nat Genet 44 (1):40-6. doi: 10.1038/ng.969.
Bianco, T., D. Hussey, and A. Dobrovic. 1999. "Methylation-sensitive, singlestrand conformation analysis (MSSSCA): A rapid method to screen for and analyze methylation." Hum Mutat 14 (4):289-93. doi: 10.1002/(SICI)10981004(199910)14:4<289::AIDHUMU3>3.0.CO;2-A.

Bibikova, M., J. Le, B. Barnes, S. SaediniaMelnyk, L. Zhou, R. Shen, and K. L. Gunderson. 2009. "Genome-wide DNA methylation profiling using Infinium(R) assay." Epigenomics 1 (1):177-200. doi: 10.2217/epi.09.14.

Bibikova, M., Z. Lin, L. Zhou, E. Chudin, E. W. Garcia, B. Wu, D. Doucet, N. J. Thomas, Y. Wang, E. Vollmer, T. Goldmann, C. Seifart, W. Jiang, D. L. Barker, M. S. Chee, J. Floros, and J. B. Fan. 2006. "High-throughput DNA methylation profiling using universal bead arrays." Genome Res 16 (3):383-93. doi: 10.1101/gr.4410706.

Boland, C. R., and A. Goel. 2010. "Microsatellite instability in colorectal cancer." Gastroenterology 138 (6):2073-2087 e3. doi: 10.1053/j.gastro.2009.12.064.

Borssen, M., L. Palmqvist, K. Karrman, J. Abrahamsson, M. Behrendtz, J. Heldrup, E. Forestier, G. Roos, and S. Degerman. 2013. "Promoter DNA methylation pattern identifies prognostic subgroups in childhood T-cell acute lymphoblastic leukemia." PLoS One 8 (6):e65373. doi: 10.1371/journal.pone.0065373.

Charlton, J., R. D. Williams, N. J. Sebire, S. Popov, G. Vujanic, T. Chagtai, M. Alcaide-German, T. Morris, L. M. Butcher, P. Guilhamon, S. Beck, and K. Pritchard-Jones. 2015. "Comparative methylome analysis identifies new tumour subtypes and biomarkers for 
transformation of nephrogenic rests into Wilms tumour." Genome Med 7 (1):11. doi: 10.1186/s13073-0150136-4.

Chatterton, Z., L. Morenos, F. Mechinaud, D. M. Ashley, J. M. Craig, A. Sexton-Oates, M. S. Halemba, M. Parkinson-Bates, J. Ng, D. Morrison, W. L. Carroll, R. Saffery, and N. C. Wong. $2014 . \quad$ "Epigenetic deregulation in pediatric acute lymphoblastic leukemia."

Epigenetics 9 (3):459-67. doi: 10.4161/epi.27585.

Chen, W. D., Z. J. Han, J. Skoletsky, J. Olson, J. Sah, L. Myeroff, P. Platzer, S. Lu, D. Dawson, J. Willis, T. P. Pretlow, J. Lutterbaugh, L. Kasturi, J. K. Willson, J. S. Rao, A. Shuber, and S. D. Markowitz. 2005.

"Detection in fecal DNA of colon cancer-specific methylation of the nonexpressed vimentin gene." J Natl Cancer Inst 97 (15):1124-32. doi: 10.1093/jnci/dji204.

Chiu, W. T., H. T. Lee, F. J. Huang, K. D. Aldape, J. Yao, P. S. Steeg, C. Y. Chou, Z. Lu, K. Xie, and S. Huang. 2011. "Caveolin-1 upregulation mediates suppression of primary breast tumor growth and brain metastases by stat 3 inhibition." Cancer Res 71 (14):4932-43. doi: 10.1158/0008-5472.CAN-10-4249.

Choudhry, H., and J. W. Catto. 2011. "Epigenetic regulation of microRNA expression in cancer." Methods $\mathrm{Mol}$ Biol 676:165-84. doi: 10.1007/9781-60761-863-8_12.

Christman, J. K., P. Price, L. Pedrinan, and G. Acs. 1977. "Correlation between hypomethylation of DNA and expression of globin genes in Friend erythroleukemia cells." Eur J Biochem 81 (1):53-61.

Collado, M., M. A. Blasco, and M. Serrano. 2007. "Cellular senescence in cancer and aging." Cell 130 (2):223-33. doi: 10.1016/j.cell.2007.07.003.
K. B. Ribeiro, I. W. Cunha, J. A. Rinck, Jr., M. O'Hare, A. Mackay, F. A. Soares, R. R. Brentani, and A. A. Camargo. 2006. "SATR-1 hypomethylation is a common and early event in breast cancer." Cancer Genet Cytogenet 165 (2):135-43. doi:

10.1016/j.cancergencyto.2005.07.02 3.

Costello, J. F., M. C. Fruhwald, D. J. Smiraglia, L. J. Rush, G. P. Robertson, X. Gao, F. A. Wright, J. D. Feramisco, P. Peltomaki, J. C. Lang, D. E. Schuller, L. Yu, C. D. Bloomfield, M. A. Caligiuri, A. Yates, R. Nishikawa, H. Su Huang, N. J. Petrelli, X. Zhang, M. S. O'Dorisio, W. A. Held, W. K. Cavenee, and C. Plass. 2000. "Aberrant CpG-island methylation has non-random and tumour-typespecific patterns." Nat Genet 24 (2):132-8. doi: 10.1038/72785.

Cunningham, J. M., E. R. Christensen, D. J. Tester, C. Y. Kim, P. C. Roche, L. J. Burgart, and S. N. Thibodeau. 1998. "Hypermethylation of the hMLH1 promoter in colon cancer with microsatellite instability." Cancer Res 58 (15):3455-60.

Dante, R. 1988. "Quantitative determination of methylated $\mathrm{CpG}$ in satellite DNA I and in L1Rn DNA sequences extracted from rat kidney tissue and from rat kidney cell lines." Eur J Biochem 175 (1):135-9.

Daskalos, A., G. Nikolaidis, G. Xinarianos, P. Savvari, A. Cassidy, R. Zakopoulou, A. Kotsinas, V. Gorgoulis, J. K. Field, and T. Liloglou. 2009. "Hypomethylation of retrotransposable elements correlates with genomic instability in non-small cell lung cancer." Int J Cancer 124 (1):81-7. doi: 10.1002/ijc.23849.

Davidsson, J., H. Lilljebjorn, A. Andersson, S. Veerla, J. Heldrup, M. Behrendtz, T. Fioretos, and B. Johansson. 2009.

Costa, F. F., V. A. Paixao, F. P. Cavalher, 
"The DNA methylome of pediatric acute lymphoblastic leukemia." Hum Mol Genet 18 (21):4054-65. doi: 10.1093/hmg/ddp354.

de Bustros, A., B. D. Nelkin, A. Silverman, G. Ehrlich, B. Poiesz, and S. B. Baylin. 1988. "The short arm of chromosome 11 is a "hot spot" for hypermethylation in human neoplasia."

Proc Natl Acad Sci U S A 85 (15):5693-7.

Decock, A., M. Ongenaert, J. Hoebeeck, K. De Preter, G. Van Peer, W. Van Criekinge, R. Ladenstein, J. H. Schulte, R. Noguera, R. L. Stallings, A. Van Damme, G. Laureys, J. Vermeulen, T. Van Maerken, F. Speleman, and J. Vandesompele. 2012. "Genome-wide promoter methylation analysis in neuroblastoma identifies prognostic methylation biomarkers." Genome Biol 13 (10):R95. doi: 10.1186/gb2012-13-10-r95.

deVos, T., R. Tetzner, F. Model, G. Weiss, M. Schuster, J. Distler, K. V. Steiger, R. Grutzmann, C. Pilarsky, J. K. Habermann, P. R. Fleshner, B. M. Oubre, R. Day, A. Z.

Sledziewski, and C. Lofton-Day. 2009. "Circulating methylated SEPT9 DNA in plasma is a biomarker for colorectal cancer." Clin Chem 55 (7):1337-46. doi: 10.1373/clinchem.2008.115808.

Djos, A., T. Martinsson, P. Kogner, and H. Caren. 2012. "The RASSF gene family members RASSF5, RASSF6 and RASSF7 show frequent DNA methylation in neuroblastoma." $\mathrm{Mol}$ Cancer 11:40. doi: 10.1186/14764598-11-40.

Dobrovic, A., and D. Simpfendorfer. 1997. "Methylation of the BRCA1 gene in sporadic breast cancer." Cancer Res 57 (16):3347-50.

Eads, C. A., K. D. Danenberg, K. Kawakami, L. B. Saltz, C. Blake, D. Shibata, P. V. Danenberg, and P. W.
Laird. 2000. "MethyLight: a highthroughput assay to measure DNA methylation." Nucleic Acids Res 28 (8):E32.

Easwaran, H., S. E. Johnstone, L. Van Neste, J. Ohm, T. Mosbruger, Q. Wang, M. J. Aryee, P. Joyce, N. Ahuja, D. Weisenberger, E. Collisson, J. Zhu, S. Yegnasubramanian, W. Matsui, and S. B. Baylin. 2012. "A DNA hypermethylation module for the stem/progenitor cell signature of cancer." Genome Res 22 (5):837-49. doi: 10.1101/gr.131169.111.

Ehrlich, M., C. B. Woods, M. C. Yu, L. Dubeau, F. Yang, M. Campan, D. J. Weisenberger, T. Long, B. Youn, E. S. Fiala, and P. W. Laird. 2006. "Quantitative analysis of associations between DNA hypermethylation, hypomethylation, and DNMT RNA levels in ovarian tumors." Oncogene 25 (18):2636-45. doi: 10.1038/sj.onc. 1209145.

Eis, P. S., W. Tam, L. Sun, A. Chadburn, Z. Li, M. F. Gomez, E. Lund, and J. E. Dahlberg. 2005. "Accumulation of miR-155 and BIC RNA in human B cell lymphomas." Proc Natl Acad Sci U S A 102 (10):3627-32. doi: 10.1073/pnas.0500613102.

Esteller, M., J. Garcia-Foncillas, E. Andion, S. N. Goodman, O. F. Hidalgo, V. Vanaclocha, S. B. Baylin, and J. G. Herman. 2000. "Inactivation of the DNA-repair gene MGMT and the clinical response of gliomas to alkylating agents." N Engl J Med 343 (19):1350-4. doi: 10.1056/NEJM200011093431901.

Esteller, M., S. R. Hamilton, P. C. Burger, S. B. Baylin, and J. G. Herman. 1999. "Inactivation of the DNA repair gene O6-methylguanine-DNA methyltransferase by promoter hypermethylation is a common event in primary human neoplasia." Cancer Res 59 (4):793-7. 
Esteller, M., J. M. Silva, G. Dominguez, F. Bonilla, X. Matias-Guiu, E. Lerma, E. Bussaglia, J. Prat, I. C. Harkes, E. A. Repasky, E. Gabrielson, M. Schutte, S. B. Baylin, and J. G. Herman. 2000. "Promoter hypermethylation and BRCA1 inactivation in sporadic breast and ovarian tumors." J Natl Cancer Inst 92 (7):564-9.

Falette, N. S., S. A. Fuqua, G. C. Chamness, M. S. Cheah, G. L. Greene, and W. L. McGuire. 1990. "Estrogen receptor gene methylation in human breast tumors." Cancer Res 50 (13):3974-8.

Fang, F., S. Turcan, A. Rimner, A. Kaufman, D. Giri, L. G. Morris, R. Shen, V. Seshan, Q. Mo, A. Heguy, S. B. Baylin, N. Ahuja, A. Viale, J. Massague, L. Norton, L. T. Vahdat, M. E. Moynahan, and T. A. Chan. 2011. "Breast cancer methylomes establish an epigenomic foundation for metastasis." Sci Transl Med 3 (75):75ra25. doi: 10.1126/scitranslmed.3001875.

Feinberg, A. P. 2004. "The epigenetics of cancer etiology." Semin Cancer Biol 14 (6):427-32. doi: 10.1016/j.semcancer.2004.06.005.

Feinberg, A. P., and B. Vogelstein. 1983. "Hypomethylation distinguishes genes of some human cancers from their normal counterparts." Nature 301 (5895):89-92.

Frigola, J., M. Ribas, R. A. Risques, and M. A. Peinado. 2002. "Methylome profiling of cancer cells by amplification of inter-methylated sites (AIMS)." Nucleic Acids Res 30 (7):e28.

Frommer, M., L. E. McDonald, D. S. Millar, C. M. Collis, F. Watt, G. W. Grigg, P. L. Molloy, and C. L. Paul. 1992. "A genomic sequencing protocol that yields a positive display of 5-methylcytosine residues in individual DNA strands." Proc Natl Acad Sci U S A 89 (5):1827-31.
Gama-Sosa, M. A., V. A. Slagel, R. W. Trewyn, R. Oxenhandler, K. C. Kuo, C. W. Gehrke, and M. Ehrlich. 1983. "The 5-methylcytosine content of DNA from human tumors." Nucleic Acids Res 11 (19):6883-94.

Gibson, S. L., A. Boquoi, T. Chen, N. E. Sharpless, C. Brensinger, and G. H. Enders. 2005. "p16(Ink4a) inhibits histologic progression and angiogenic signaling in min colon tumors." Cancer Biol Ther 4 (12):1389-94.

Gitan, R. S., H. Shi, C. M. Chen, P. S. Yan, and T. H. Huang. 2002.

"Methylation-specific oligonucleotide microarray: a new potential for high-throughput methylation analysis." Genome Res 12 (1):158-64. doi: 10.1101/gr.202801.

Goelz, S. E., B. Vogelstein, S. R. Hamilton, and A. P. Feinberg. 1985. "Hypomethylation of DNA from benign and malignant human colon neoplasms." Science 228 (4696):18790.

Gonzalgo, M. L., G. Liang, C. H. Spruck, 3rd, J. M. Zingg, W. M. Rideout, 3rd, and P. A. Jones. 1997. "Identification and characterization of differentially methylated regions of genomic DNA by methylation-sensitive arbitrarily primed PCR." Cancer Res 57 (4):5949.

Graziano, F., F. Arduini, A. Ruzzo, A. Mandolesi, I. Bearzi, R. Silva, P. Muretto, E. Testa, D. Mari, M. Magnani, M. Scartozzi, and S. Cascinu. 2004. "Combined analysis of E-cadherin gene (CDH1) promoter hypermethylation and Ecadherin protein expression in patients with gastric cancer: implications for treatment with demethylating drugs." Ann Oncol 15 (3):489-92.

Graff, J.R., J.G. Herman, R.G. Lapidus, H. Chopra, R. Xu, D.F. Jarrard, W.B. Isaacs, P.M. Pitha, N.E. Davidson, 
and S.B. Baylin. 19951. "E-cadherin expression is silenced by DNA hypermethylation in human breast and prostate carcinomas." Cancer Res 55 (22):5195-5199

Greger, V., E. Passarge, W. Hopping, E. Messmer, and B. Horsthemke. 1989. "Epigenetic changes may contribute to the formation and spontaneous regression of retinoblastoma." Hum Genet 83 (2):155-8.

Guenther, M. G., S. S. Levine, L. A. Boyer, R. Jaenisch, and R. A. Young. 2007. "A chromatin landmark and transcription initiation at most promoters in human cells." Cell 130 (1):77-88. doi: 10.1016/j.cell.2007.05.042.

Hammond, S. M. 2006. "MicroRNAs as oncogenes." Curr Opin Genet Dev 16 (1):4-9. doi: 10.1016/j.gde.2005.12.005.

Hansen, K. D., W. Timp, H. C. Bravo, S. Sabunciyan, B. Langmead, O. G. McDonald, B. Wen, H. Wu, Y. Liu, D. Diep, E. Briem, K. Zhang, R. A. Irizarry, and A. P. Feinberg. 2011. "Increased methylation variation in epigenetic domains across cancer types." Nat Genet 43 (8):768-75. doi: 10.1038/ng.865.

He, L., J. M. Thomson, M. T. Hemann, E. Hernando-Monge, D. Mu, S. Goodson, S. Powers, C. CordonCardo, S. W. Lowe, G. J. Hannon, and S. M. Hammond. 2005. "A microRNA polycistron as a potential human oncogene." Nature 435 (7043):828-33. doi: 10.1038/nature03552.

Heller, G., M. Weinzierl, C. Noll, V. Babinsky, B. Ziegler, C. Altenberger, C. Minichsdorfer, G. Lang, B. Dome, A. EndPfutzenreuter, B. M. Arns, Y. Grin, W. Klepetko, C. C. Zielinski, and S. Zochbauer-Muller. 2012. "Genomewide miRNA expression profiling identifies miR-9-3 and miR-193a as targets for DNA methylation in non- small cell lung cancers." Clin Cancer Res 18 (6):1619-29. doi: 10.1158/1078-0432.CCR-11-2450.

Herman, J. G., J. R. Graff, S. Myohanen, B. D. Nelkin, and S. B. Baylin. 1996. "Methylation-specific PCR: a novel PCR assay for methylation status of CpG islands." Proc Natl Acad Sci U S A 93 (18):9821-6.

Herman, J. G., A. Merlo, L. Mao, R. G. Lapidus, J. P. Issa, N. E. Davidson, D. Sidransky, and S. B. Baylin. 1995. "Inactivation of the CDKN2/p16/MTS1 gene is frequently associated with aberrant DNA methylation in all common human cancers." Cancer Res 55 (20):4525-30.

Herman, J. G., A. Umar, K. Polyak, J. R. Graff, N. Ahuja, J. P. Issa, S. Markowitz, J. K. Willson, S. R. Hamilton, K. W. Kinzler, M. F. Kane, R. D. Kolodner, B. Vogelstein, T. A. Kunkel, and S. B. Baylin. 1998. "Incidence and functional consequences of hMLH1 promoter hypermethylation in colorectal carcinoma." Proc Natl Acad Sci U S A 95 (12):6870-5.

Hernandez-Vargas, H., M. Ouzounova, F. Le Calvez-Kelm, M. P. Lambert, S. McKay-Chopin, S. V. Tavtigian, A. Puisieux, C. Matar, and Z. Herceg. 2011. "Methylome analysis reveals Jak-STAT pathway deregulation in putative breast cancer stem cells." Epigenetics 6 (4):428-39.

Hill, V. K., C. Ricketts, I. Bieche, S. Vacher, D. Gentle, C. Lewis, E. R. Maher, and F. Latif. 2011. "Genome-wide DNA methylation profiling of $\mathrm{CpG}$ islands in breast cancer identifies novel genes associated with tumorigenicity." Cancer Res 71 (8):2988-99. doi: 10.1158/00085472.CAN-10-4026.

Hinoue, T., D. J. Weisenberger, C. P. Lange, H. Shen, H. M. Byun, D. Van Den Berg, S. Malik, F. Pan, H. 
Noushmehr, C. M. van Dijk, R. A. Tollenaar, and P. W. Laird. 2012. "Genome-scale analysis of aberrant DNA methylation in colorectal cancer." Genome Res 22 (2):271-82. doi: 10.1101/gr.117523.110.

Hon, G. C., R. D. Hawkins, O. L. Caballero, C. Lo, R. Lister, M. Pelizzola, A. Valsesia, Z. Ye, S. Kuan, L. E. Edsall, A. A. Camargo, B. J. Stevenson, J. R. Ecker, V. Bafna, R. L. Strausberg, A. J. Simpson, and B. Ren. 2012. "Global DNA hypomethylation coupled to repressive chromatin domain formation and gene silencing in breast cancer." Genome Res 22 (2):246-58. doi: 10.1101/gr.125872.111.

Hotchkiss, R. D. 1948. "The quantitative separation of purines, pyrimidines, and nucleosides by paper chromatography." J Biol Chem 175 (1):315-32.

Hughes, L. A., V. Melotte, J. de Schrijver, M. de Maat, V. T. Smit, J. V. Bovee, P. J. French, P. A. van den Brandt, L. J. Schouten, T. de Meyer, W. van Criekinge, N. Ahuja, J. G. Herman, M. P. Weijenberg, and M. van Engeland. 2013. "The CpG island methylator phenotype: what's in a name?" Cancer Res 73 (19):5858-68. doi: 10.1158/0008-5472.CAN-124306.

Itzkowitz, S., R. Brand, L. Jandorf, K. Durkee, J. Millholland, L. Rabeneck, P. C. Schroy, 3rd, S. Sontag, D. Johnson, S. Markowitz, L. Paszat, and B. M. Berger. 2008. "A simplified, noninvasive stool DNA test for colorectal cancer detection." Am J Gastroenterol 103 (11):2862-70. doi: 10.1111/j.15720241.2008.02088.x.

Jadhav, R. R., Z. Ye, R. L. Huang, J. Liu, P. Y. Hsu, Y. W. Huang, L. B. Rangel, H. C. Lai, J. C. Roa, N. B. Kirma, T. H. Huang, and V. X. Jin. 2015. "Genome-wide DNA methylation analysis reveals estrogen-mediated epigenetic repression of metallothionein-1 gene cluster in breast cancer." Clin Epigenetics 7 (1):13. doi: 10.1186/s13148-0150045-9.

Johnson, S. M., H. Grosshans, J. Shingara, M. Byrom, R. Jarvis, A. Cheng, E. Labourier, K. L. Reinert, D. Brown, and F. J. Slack. 2005. "RAS is regulated by the let-7 microRNA family." Cell 120 (5):635-47. doi: 10.1016/j.cell.2005.01.014.

Jones, P. A., and S. B. Baylin. "The Fundamental Role of Epigenetic Events in Cancer." Nature Reviews Genetics 3, no. 6 (2002): 415-28.

Kang, J. Y., S. H. Song, J. Yun, M. S. Jeon, Y. Cha, S. H. Lee, H. P. Kim, E. G. Jeong, S. W. Han, N. Y. Cho, M. C. Kook, G. H. Kang, and T. Y. Kim. 2015. "Identification of long-range epigenetic silencing on chromosome $15 \mathrm{q} 25$ and its clinical implication in gastric cancer." Am J Pathol 185 (3):666-78. doi: 10.1016/j.ajpath.2014.11.022.

Katzenellenbogen, R. A., S. B. Baylin, and J. G. Herman. 1999. "Hypermethylation of the DAPkinase $\mathrm{CpG}$ island is a common alteration in B-cell malignancies." Blood 93 (12):4347-53.

Kelley, D. E., B. A. Pollok, M. L. Atchison, and R. P. Perry. 1988. "The coupling between enhancer activity and hypomethylation of kappa immunoglobulin genes is developmentally regulated." $\mathrm{Mol}$ Cell Biol 8 (2):930-7.

Keshet, I., Y. Schlesinger, S. Farkash, E. Rand, M. Hecht, E. Segal, E. Pikarski, R. A. Young, A. Niveleau, H. Cedar, and I. Simon. 2006. "Evidence for an instructive mechanism of de novo methylation in cancer cells." Nat Genet 38 (2):149-53. doi: 10.1038/ng1719.

Khulan, B., R. F. Thompson, K. Ye, M. J. Fazzari, M. Suzuki, E. Stasiek, M. E. 
Figueroa, J. L. Glass, Q. Chen, C. Montagna, E. Hatchwell, R. R. Selzer, T. A. Richmond, R. D. Green, A. Melnick, and J. M. Greally. 2006. "Comparative isoschizomer profiling of cytosine methylation: the HELP assay." Genome Res 16 (8):1046-55. doi: 10.1101/gr.5273806.

Kissil, J. L., E. Feinstein, O. Cohen, P. A. Jones, Y. C. Tsai, M. A. Knowles, M. E. Eydmann, and A. Kimchi. 1997. "DAP-kinase loss of expression in various carcinoma and B-cell lymphoma cell lines: possible implications for role as tumor suppressor gene." Oncogene 15 (4):403-7. doi: 10.1038/sj.onc.1201172.

Kneip, C., B. Schmidt, A. Seegebarth, S. Weickmann, M. Fleischhacker, V. Liebenberg, J. K. Field, and D. Dietrich. 2011. "SHOX2 DNA methylation is a biomarker for the diagnosis of lung cancer in plasma." J Thorac Oncol 6 (10):1632-8. doi: 10.1097/JTO.0b013e318220ef9a.

Kunej, T., I. Godnic, J. Ferdin, S. Horvat, P. Dovc, and G. A. Calin. 2011. "Epigenetic regulation of microRNAs in cancer: an integrated review of literature." Mutat Res 717 (1-2):77-84. doi: 10.1016/j.mrfmmm.2011.03.008.

Lehmann, U., B. Hasemeier, M. Christgen, M. Muller, D. Romermann, F. Langer, and H. Kreipe. 2008. "Epigenetic inactivation of microRNA gene hsa-mir-9-1 in human breast cancer." J Pathol 214 (1):17-24. doi: 10.1002/path.2251.

Lesch, B. J., and D. C. Page. 2014. "Poised chromatin in the mammalian germ line." Development 141 (19):361926. doi: 10.1242/dev.113027.

Lewis, B. P., C. B. Burge, and D. P. Bartel. 2005. "Conserved seed pairing, often flanked by adenosines, indicates that thousands of human genes are microRNA targets." Cell 120 (1):15-
20. doi: 10.1016/j.cell.2004.12.035.

Lister, R., R. C. O'Malley, J. Tonti-Filippini, B. D. Gregory, C. C. Berry, A. H. Millar, and J. R. Ecker. 2008. "Highly integrated single-base resolution maps of the epigenome in Arabidopsis." Cell 133 (3):523-36. doi: 10.1016/j.cell.2008.03.029.

Lister, R., M. Pelizzola, Y. S. Kida, R. D. Hawkins, J. R. Nery, G. Hon, J. Antosiewicz-Bourget, R. O'Malley, R. Castanon, S. Klugman, M. Downes, R. Yu, R. Stewart, B. Ren, J. A. Thomson, R. M. Evans, and J. R. Ecker. 2011. "Hotspots of aberrant epigenomic reprogramming in human induced pluripotent stem cells." Nature 471 (7336):68-73. doi: 10.1038/nature09798.

Liteplo, R. G., P. Frost, and R. S. Kerbel. 1984. "5-azacytidine induction of thymidine kinase in a spontaneously enzyme-deficient murine tumor line." Exp Cell Res 150 (2):499-504.

Liu, P., M. Rudick, and R. G. Anderson. 2002. "Multiple functions of caveolin-1." J Biol Chem 277 (44):41295-8. doi: 10.1074/jbc.R200020200.

Loriot, A., A. Van Tongelen, J. Blanco, S. Klaessens, J. Cannuyer, N. van Baren, A. Decottignies, and C. De Smet. 2014. "A novel cancergermline transcript carrying prometastatic miR-105 and TETtargeting miR-767 induced by DNA hypomethylation in tumors." Epigenetics 9 (8):1163-71. doi: 10.4161/epi.29628.

Lu, C., P. S. Ward, G. S. Kapoor, D. Rohle, S. Turcan, O. Abdel-Wahab, C. R. Edwards, R. Khanin, M. E. Figueroa, A. Melnick, K. E. Wellen, D. M. O'Rourke, S. L. Berger, T. A. Chan, R. L. Levine, I. K. Mellinghoff, and C. B. Thompson. 2012. "IDH mutation impairs histone demethylation and results in a block to cell differentiation." Nature 483 (7390):474-8. doi: 
10.1038/nature10860.

Merlo, A., J. G. Herman, L. Mao, D. J. Lee, E. Gabrielson, P. C. Burger, S. B. Baylin, and D. Sidransky. 1995. "5' $\mathrm{CpG}$ island methylation is associated with transcriptional silencing of the tumour suppressor p16/CDKN2/MTS1 in human cancers." Nat Med 1 (7):686-92.

Nishida, N., M. Kudo, T. Nishimura, T. Arizumi, M. Takita, S. Kitai, N. Yada, S. Hagiwara, T. Inoue, Y. Minami, K. Ueshima, T. Sakurai, N. Yokomichi, T. Nagasaka, and A. Goel. 2013. "Unique association between global DNA hypomethylation and chromosomal alterations in human hepatocellular carcinoma." PLoS One 8 (9):e72312. doi: 10.1371/journal.pone.0072312.

Noushmehr, H., D. J. Weisenberger, K. Diefes, H. S. Phillips, K. Pujara, B. P. Berman, F. Pan, C. E. Pelloski, E. P. Sulman, K. P. Bhat, R. G. Verhaak, K. A. Hoadley, D. N. Hayes, C. M. Perou, H. K. Schmidt, L. Ding, R. K. Wilson, D. Van Den Berg, H. Shen, H. Bengtsson, P. Neuvial, L. M. Cope, J. Buckley, J. G. Herman, S. B. Baylin, P. W. Laird, K. Aldape, and Network Cancer Genome Atlas Research. 2010. "Identification of a $\mathrm{CpG}$ island methylator phenotype that defines a distinct subgroup of glioma." Cancer Cell 17 (5):510-22. doi: 10.1016/j.ccr.2010.03.017.

Novak, P., T. Jensen, M. M. Oshiro, G. S. Watts, C. J. Kim, and B. W. Futscher. 2008. "Agglomerative epigenetic aberrations are a common event in human breast cancer." Cancer Res 68 (20):8616-25. doi: 10.1158/0008-5472.CAN-08-1419.

Nyren, P. 1987. "Enzymatic method for continuous monitoring of DNA polymerase activity." Anal Biochem 167 (2):235-8.

Ogawa, H., X. Wu, K. Kawamoto, N. Nishida, M. Konno, J. Koseki, H.
Matsui, K. Noguchi, N. Gotoh, T. Yamamoto, K. Miyata, N. Nishiyama, H. Nagano, H. Yamamoto, S. Obika, K. Kataoka, Y. Doki, M. Mori, and H. Ishii. 2015. "MicroRNAs Induce Epigenetic Reprogramming and Suppress Malignant Phenotypes of Human Colon Cancer Cells." PLoS One 10 (5):e0127119. doi: 10.1371/journal.pone.0127119.

Ohm, J. E., K. M. McGarvey, X. Yu, L. Cheng, K. E. Schuebel, L. Cope, H. P. Mohammad, W. Chen, V. C. Daniel, W. Yu, D. M. Berman, T. Jenuwein, K. Pruitt, S. J. Sharkis, D. N. Watkins, J. G. Herman, and S. B. Baylin. 2007. "A stem cell-like chromatin pattern may predispose tumor suppressor genes to DNA hypermethylation and heritable silencing." Nat Genet 39 (2):237-42. doi: 10.1038/ng1972.

Okochi-Takada, E., N. Hattori, T.

Tsukamoto, K. Miyamoto, T. Ando, S. Ito,Y. Yamamura, M.

Wakabayachi, Y. Nobeyama, and T. Ushijima. 2014. "ANGPTL4 is a secreted tumor suppressor that inhibits angiogenesis." Oncogene 33 (17):2273-2278

Orita, M., H. Iwahana, H. Kanazawa, K. Hayashi, and T. Sekiya. 1989. "Detection of polymorphisms of human DNA by gel electrophoresis as single-strand conformation polymorphisms." Proc Natl Acad Sci US A 86 (8):2766-70.

Palmisano, W. A., K. K. Divine, G. Saccomanno, F. D. Gilliland, S. B. Baylin, J. G. Herman, and S. A. Belinsky. 2000. "Predicting lung cancer by detecting aberrant promoter methylation in sputum." Cancer Res 60 (21):5954-8.

Payne, S. R. 2010. "From discovery to the clinic: the novel DNA methylation biomarker (m)SEPT9 for the detection of colorectal cancer in blood." Epigenomics 2 (4):575-85. 
doi: 10.2217/epi.10.35.

Piva, R., A. P. Rimondi, S. Hanau, I. Maestri, A. Alvisi, V. L. Kumar, and L. del Senno. 1990. "Different methylation of oestrogen receptor DNA in human breast carcinomas with and without oestrogen receptor." Br J Cancer 61 (2):270-5.

Rao, X., J. Evans, H. Chae, J. Pilrose, S. Kim, P. Yan, R. L. Huang, H. C. Lai, H. Lin, Y. Liu, D. Miller, J. K. Rhee, Y. W. Huang, F. Gu, J. W. Gray, T. M. Huang, and K. P. Nephew. 2013. "CpG island shore methylation regulates caveolin-1 expression in breast cancer." Oncogene 32 (38):4519-28. doi: 10.1038/onc.2012.474.

Reinders, J., C. Delucinge Vivier, G. Theiler, D. Chollet, P. Descombes, and J. Paszkowski. 2008. "Genome-wide, high-resolution DNA methylation profiling using bisulfite-mediated cytosine conversion." Genome Res 18 (3):469-76. doi: 10.1101/gr.7073008.

Reyngold, M., S. Turcan, D. Giri, K. Kannan, L. A. Walsh, A. Viale, M. Drobnjak, L. T. Vahdat, W. Lee, and T. A. Chan. 2014. "Remodeling of the methylation landscape in breast cancer metastasis." PLoS One 9 (8):e103896. doi:

10.1371/journal.pone.0103896.

Richards, K. L., B. Zhang, K. A. Baggerly, S. Colella, J. C. Lang, D. E. Schuller, and R. Krahe. 2009. "Genome-wide hypomethylation in head and neck cancer is more pronounced in HPV-negative tumors and is associated with genomic instability." PLoS One 4 (3):e4941. doi: 10.1371/journal.pone.0004941.

Robertson, G., M. Hirst, M. Bainbridge, M. Bilenky, Y. Zhao, T. Zeng, G. Euskirchen, B. Bernier, R. Varhol, A. Delaney, N. Thiessen, O. L. Griffith, A. He, M. Marra, M. Snyder, and S. Jones. 2007. "Genome-wide profiles of STAT1 DNA association using chromatin immunoprecipitation and massively parallel sequencing." Nat Methods 4 (8):651-7. doi: 10.1038/nmeth1068.

Ronaghi, M. 2001. "Pyrosequencing sheds light on DNA sequencing." Genome Res 11 (1):3-11. Ronaghi, M., S. Karamohamed, B. Pettersson, M. Uhlen, and P. Nyren. 1996. "Realtime DNA sequencing using detection of pyrophosphate release." Anal Biochem 242 (1):84-9. doi: 10.1006/abio.1996.0432.

Sakai, T., J. Toguchida, N. Ohtani, D. W. Yandell, J. M. Rapaport, and T. P. Dryja. 1991. "Allele-specific hypermethylation of the retinoblastoma tumor-suppressor gene." Am J Hum Genet 48 (5):8808.

Samowitz, W. S., H. Albertsen, J. Herrick, T. R. Levin, C. Sweeney, M. A. Murtaugh, R. K. Wolff, and M. L. Slattery. 2005. "Evaluation of a large, population-based sample supports a $\mathrm{CpG}$ island methylator phenotype in colon cancer." Gastroenterology 129 (3):837-45. doi: 10.1053/j.gastro.2005.06.020.

Sandoval, J., H. Heyn, J. Mendez-Gonzalez, A. Gomez, S. Moran, M. Baiget, M. Melo, I. Badell, J. F. Nomdedeu, and M. Esteller. 2013. "Genome-wide DNA methylation profiling predicts relapse in childhood B-cell acute lymphoblastic leukaemia." $\mathrm{Br} J$ Haematol 160 (3):406-9. doi: 10.1111/bjh.12113.

Savage, K., M. B. Lambros, D. Robertson, R. L. Jones, C. Jones, A. Mackay, M. James, J. L. Hornick, E. M. Pereira, F. Milanezi, C. D. Fletcher, F. C. Schmitt, A. Ashworth, and J. S. Reis-Filho. 2007. "Caveolin 1 is overexpressed and amplified in a subset of basal-like and metaplastic breast carcinomas: a morphologic, ultrastructural, immunohistochemical, and in situ hybridization analysis." Clin Cancer 
Res 13 (1):90-101. doi: 10.1158/1078-0432.CCR-06-1371.

Schmidt, B., V. Liebenberg, D. Dietrich, T. Schlegel, C. Kneip, A. Seegebarth, N. Flemming, S. Seemann, J. Distler, J. Lewin, R. Tetzner, S. Weickmann, U. Wille, T. Liloglou, O. Raji, M. Walshaw, M.

Fleischhacker, C. Witt, and J. K. Field. 2010. "SHOX2 DNA methylation is a biomarker for the diagnosis of lung cancer based on bronchial aspirates." BMC Cancer 10:600. doi: 10.1186/1471-2407-10600.

Sheffield, V. C., J. S. Beck, A. E. Kwitek, D. W. Sandstrom, and E. M. Stone. 1993. "The sensitivity of singlestrand conformation polymorphism analysis for the detection of single base substitutions." Genomics 16 (2):325-32. doi: 10.1006/geno.1993.1193.

Shen, L., H. Kantarjian, Y. Guo, E. Lin, J. Shan, X. Huang, D. Berry, S. Ahmed, W. Zhu, S. Pierce, Y. Kondo, Y. Oki, J. Jelinek, H. Saba, E. Estey, and J. P. Issa. 2010. "DNA methylation predicts survival and response to therapy in patients with myelodysplastic syndromes." J Clin Oncol 28 (4):605-13. doi: 10.1200/JCO.2009.23.4781.

Shen, L., M. Toyota, Y. Kondo, E. Lin, L. Zhang, Y. Guo, N. S. Hernandez, X. Chen, S. Ahmed, K. Konishi, S. R. Hamilton, and J. P. Issa. 2007. "Integrated genetic and epigenetic analysis identifies three different subclasses of colon cancer." Proc Natl Acad Sci U S A 104

(47):18654-9. doi: 10.1073/pnas.0704652104.

Simons, C. C., L. A. Hughes, K. M. Smits, C. A. Khalid-de Bakker, A. P. de Bruine, B. Carvalho, G. A. Meijer, L. J. Schouten, P. A. van den Brandt, M. P. Weijenberg, and M. van Engeland. 2013. "A novel classification of colorectal tumors based on microsatellite instability, the $\mathrm{CpG}$ island methylator phenotype and chromosomal instability: implications for prognosis." Ann Oncol 24 (8):2048-56. doi: 10.1093/annonc/mdt076.

Spandidos, D. A. 1986. "A unified theory for the development of cancer." Biosci Rep 6 (8):691-708.

Strahl, B. D., and C. D. Allis. 2000. "The language of covalent histone modifications." Nature 403 (6765):41-5. doi: 10.1038/47412.

Tanemura, A., A. M. Terando, M. S. Sim, A. Q. van Hoesel, M. F. de Maat, D. L. Morton, and D. S. Hoon. 2009. "CpG island methylator phenotype predicts progression of malignant melanoma." Clin Cancer Res 15 (5):1801-7. doi: 10.1158/1078-0432.CCR-08-1361.

Tanzer, M., B. Balluff, J. Distler, K. Hale, A. Leodolter, C. Rocken, B. Molnar, R. Schmid, C. Lofton-Day, T. Schuster, and M. P. Ebert. 2010. "Performance of epigenetic markers SEPT9 and ALX4 in plasma for detection of colorectal precancerous lesions." PLoS One 5 (2):e9061. doi: 10.1371/journal.pone.0009061.

Taube, J. H., G. G. Malouf, E. Lu, N. Sphyris, V. Vijay, P. P. Ramachandran, K. R. Ueno, S. Gaur, M. S. Nicoloso, S. Rossi, J. I. Herschkowitz, J. M. Rosen, J. P. Issa, G. A. Calin, J. T. Chang, and S. A. Mani. 2013. "Epigenetic silencing of microRNA-203 is required for EMT and cancer stem cell properties." Sci Rep 3:2687. doi: 10.1038/srep02687.

Thirlwell, C., A. Feber, M. Lechner, A. E. Teschendorff, and S. Beck. 2012. "Comments on: Interpretation of genome-wide infinium methylation data from ligated DNA in formalinfixed paraffin-embedded paired tumor and normal tissue." BMC Res Notes 5:631. doi: 10.1186/17560500-5-631. 
Timp, W., and A. P. Feinberg. 2013. "Cancer as a dysregulated epigenome allowing cellular growth advantage at the expense of the host." Nat Rev Cancer 13 (7):497510. doi: $10.1038 / \mathrm{nrc} 3486$.

Tiwari, N., V. K. Tiwari, L. Waldmeier, P. J. Balwierz, P. Arnold, M. Pachkov, N. Meyer-Schaller, D. Schubeler, E. van Nimwegen, and G. Christofori. 2013. "Sox4 is a master regulator of epithelial-mesenchymal transition by controlling Ezh2 expression and epigenetic reprogramming." Cancer Cell 23 (6):768-83. doi: 10.1016/j.ccr.2013.04.020.

Toyota, M., N. Ahuja, M. Ohe-Toyota, J. G. Herman, S. B. Baylin, and J. P. Issa. 1999. "CpG island methylator phenotype in colorectal cancer." Proc Natl Acad Sci U S A 96 (15):8681-6.

Toyota, M., C. Ho, N. Ahuja, K. W. Jair, Q. Li, M. Ohe-Toyota, S. B. Baylin, and J. P. Issa. 1999. "Identification of differentially methylated sequences in colorectal cancer by methylated CpG island amplification." Cancer Res 59 (10):2307-12.

Turcan, S., D. Rohle, A. Goenka, L. A. Walsh, F. Fang, E. Yilmaz, C. Campos, A. W. Fabius, C. Lu, P. S. Ward, C. B. Thompson, A. Kaufman, O. Guryanova, R. Levine, A. Heguy, A. Viale, L. G. Morris, J. T. Huse, I. K. Mellinghoff, and T. A. Chan. 2012. "IDH1 mutation is sufficient to establish the glioma hypermethylator phenotype." Nature 483 (7390):479-83. doi: 10.1038/nature10866.

Vedeld, H. M., K. Andresen, I. A. Eilertsen, A. Nesbakken, R. Seruca, I. P. Gladhaug, E. Thiis-Evensen, T. O. Rognum, K. M. Boberg, and G. E. Lind. 2015. "The novel colorectal cancer biomarkers CDO1, ZSCAN18 and ZNF331 are frequently methylated across gastrointestinal cancers." Int J Cancer 136 (4):84453. doi: 10.1002/ijc. 29039.

Vire, E., C. Brenner, R. Deplus, L. Blanchon, M. Fraga, C. Didelot, L. Morey, A. Van Eynde, D. Bernard, J. M. Vanderwinden, M. Bollen, M. Esteller, L. Di Croce, Y. de Launoit, and F. Fuks. 2006. "The Polycomb group protein EZH2 directly controls DNA methylation." Nature 439 (7078):871-4. doi: 10.1038/nature04431.

Waddington, C. H. 2012. "The epigenotype. 1942." Int J Epidemiol 41 (1):10-3. doi: $10.1093 /$ ije/dyr 184 .

Weisenberger, D. J., K. D. Siegmund, M. Campan, J. Young, T. I. Long, M. A. Faasse, G. H. Kang, M. Widschwendter, D. Weener, D. Buchanan, H. Koh, L. Simms, M. Barker, B. Leggett, J. Levine, M. Kim, A. J. French, S. N. Thibodeau, J. Jass, R. Haile, and P. W. Laird. 2006. "CpG island methylator phenotype underlies sporadic microsatellite instability and is tightly associated with BRAF mutation in colorectal cancer." Nat Genet 38 (7):787-93. doi: 10.1038/ng1834.

Wong, N. C., D. Ashley, Z. Chatterton, M. Parkinson-Bates, H. K. Ng, M. S. Halemba, A. Kowalczyk, J. Bedo, Q. Wang, K. Bell, E. Algar, J. M. Craig, and R. Saffery. 2012. "A distinct DNA methylation signature defines pediatric pre-B cell acute lymphoblastic leukemia." Epigenetics 7 (6):535-41. doi: 10.4161/epi.20193.

Xu, Y., B. Hu, A. J. Choi, B. Gopalan, B. H. Lee, M. F. Kalady, J. M. Church, and A. H. Ting. 2012. "Unique DNA methylome profiles in $\mathrm{CpG}$ island methylator phenotype colon cancers." Genome Res 22 (2):283-91. doi: $10.1101 / \mathrm{gr} .122788 .111$.

Yan, P., D. Frankhouser, M. Murphy, H. H. Tam, B. Rodriguez, J. Curfman, M. Trimarchi, S. Geyer, Y. Z. Wu, S. P. 
Whitman, K. Metzeler, A. Walker, R. Klisovic, S. Jacob, M. R. Grever, J. C. Byrd, C. D. Bloomfield, R. Garzon, W. Blum, M. A. Caligiuri, R. Bundschuh, and G. Marcucci. 2012. "Genome-wide methylation profiling in decitabine-treated patients with acute myeloid leukemia." Blood 120 (12):2466-74. doi: 10.1182/blood-2012-05-429175.

Zhang, B., W. Zhu, P. Yang, T. Liu, M. Jiang, Z. N. He, S. X. Zhang, W. Q. Chen, and W. Chen. 2011.

"Cigarette smoking and p16INK4alpha gene promoter hypermethylation in non-small cell lung carcinoma patients: a metaanalysis." PLoS One 6 (12):e28882. doi: 10.1371/journal.pone.0028882.

Zhang, X., J. Yazaki, A. Sundaresan, S. Cokus, S. W. Chan, H. Chen, I. R. Henderson, P. Shinn, M. Pellegrini, S. E. Jacobsen, and J. R. Ecker. 2006. "Genome-wide highresolution mapping and functional analysis of DNA methylation in arabidopsis." Cell 126 (6):1189-201. doi: 10.1016/j.cell.2006.08.003.

Zhao, X., F. Yang, S. Li, M. Liu, S. Ying, X. Jia, and X. Wang. 2014. "CpG island methylator phenotype of myelodysplastic syndrome identified through genome-wide profiling of DNA methylation and gene expression." Br J Haematol 165 (5):649-58. doi: 10.1111/bjh.12811.

Zilberman, D., M. Gehring, R. K. Tran, T. Ballinger, and S. Henikoff. 2007. "Genome-wide analysis of Arabidopsis thaliana DNA methylation uncovers an interdependence between methylation and transcription." Nat Genet 39 (1):61-9. doi: $10.1038 / n g 1929$. 